\title{
Transfer of Dietary Zinc and Fat to Milk-Evaluation of Milk Fat Quality, Milk Fat Precursors, and Mastitis Indicators
}

\author{
L. Wiking, ${ }^{\star 1}$ T. Larsen, $\dagger$ and J. Sehested $†$ \\ *Department of Food Science, and \\ †Department of Animal Health, Welfare and Nutrition, Faculty of Agricultural Sciences, University of Aarhus, \\ Research Centre Foulum, PO Box 50, DK-8830 Tjele, Denmark
}

\begin{abstract}
The present study demonstrated that the zinc concentration in bovine milk and blood plasma is significantly affected by the intake of saturated fat supplements. Sixteen Holstein cows were used in a $4 \times 4$ Latin square design with 4 periods of $12 \mathrm{~d}$, and 4 dietary treatments were conducted. A total mixed ration based on corn silage, grass-clover silages, and pelleted sugar beet pulp was used on all treatments. A high de novo milk fat diet was formulated by adding rapeseed meal and molasses in the total mixed ration [39 $\mathrm{mg}$ of $\mathrm{Zn} / \mathrm{kg}$ of dry matter (DM)], and a low de novo diet by adding saturated fat, fat-rich rapeseed cake, and corn (34 $\mathrm{mg}$ of $\mathrm{Zn} / \mathrm{kg}$ of DM). Dietary $\mathrm{Zn}$ levels were increased by addition of $\mathrm{ZnO}$ to 83 and $80 \mathrm{mg}$ of $\mathrm{Zn} / \mathrm{kg}$ of DM. Treatments did not affect daily DM intake, or yield of energy-corrected milk, milk fat, or milk protein. The high de novo diet significantly increased milk fat percentage and milk content of fatty acids with chain length from $\mathrm{C} 6$ to $\mathrm{C} 16$, and decreased content of $\mathrm{C} 18$ and C18:1. Treatments did not influence milk free fatty acids at $4^{\circ} \mathrm{C}$ at 0 or $28 \mathrm{~h}$ after milking. The average diameter of milk fat globules was significantly greater in milk from cows offered low de novo diets. Furthermore, the low de novo diet significantly increased the concentration of nonesterified fatty acids and D- $\beta$-hydroxybutyrate in blood plasma, the latter was also increased in milk. Treatments did not affect the enzyme activity of lactate dehydrogenase and $\mathrm{N}$-acetyl- $\beta$-D-glucosaminidase in milk or the activity of isocitrate dehydrogenase and malate dehydrogenase in blood plasma. The low de novo diet significantly increased plasma $\mathrm{Zn}$ and milk Zn content, whereas dietary $\mathrm{Zn}$ level did not in itself influence these parameters. This indicates that the transfer of fat from diet to milk might facilitate transfer of $\mathrm{Zn}$ from diet to milk.
\end{abstract}

Received September 24, 2007.

Accepted December 11, 2007.

${ }^{1}$ Corresponding author: lars.wiking@agrsci.dk
Key words: milk fat, zinc, free fatty acid, milk fat globule

\section{INTRODUCTION}

Fat supplements to dairy cows often result in increased milk yield and milk fat production, especially when feeding saturated fat (Chilliard, 1993). It is well documented that milk fat composition is affected by the level and source of dietary fat. The milk fatty acids (FA) containing from 4 to 14 carbon atoms are mainly synthesized in the mammary gland (de novo synthesis) from acetate, which is a product of the fermentation of carbohydrates in the rumen, and from BHBA, which is oxidized butyrate from rumen or produced in the liver during degradation of FFA. Some of the palmitic acid (C16:0) is also synthesized de novo. Milk long-chain FA (i.e., those containing 16 or more carbon atoms) are provided to the glands from the blood stream and originate directly from the diet or from the adipose tissue. Palmitic (C16:0) and stearic (C18:0) acids pass through the rumen unchanged, whereas unsaturated FA are subjected to biohydrogenation by the reducing environment caused by the microorganisms in the rumen, resulting mainly in stearic acid together with a smaller amount of oleic acid (C18:1). Furthermore, stearic acid derived from the diet is partly converted to oleic acid by stearoyl-CoA desaturase, in the intestine and the mammary tissue.

The disadvantage of feeding saturated lipid supplement is that it may impair the milk quality in terms of increased concentration of FFA (Astrup et al., 1980; Wiking et al., 2003, 2005). Earlier studies have shown that feeding high levels of saturated lipid supplements to dairy cows results in milk containing large milk fat globules (MFG; volume-based average diameter) (Wiking et al., 2003, 2004). These large MFG are less stable against pumping of milk, which results in greater concentrations of FFA in the milk (Wiking et al., 2003, 2005), associated with rancid flavor. Additionally, a study has indicated that supplementary dietary $\mathrm{Zn}$ 
might reduce the formation of FFA in milk (Hermansen et al., 1995).

Zinc is the trace element in milk that is present in the largest concentration and the literature reports average values from 3.5 to $4 \mathrm{mg} / \mathrm{kg}$ (Johnson, 1974; Anderson, 1992) for normal dairy cows. Zinc is generally considered to be a stabilizing agent of biological membranes (Chvapil, 1976; Lindén et al., 2004). In milk, $\mathrm{Zn}$ is found in the milk fat globule membrane (MFGM; Mulder and Walstra, 1974), presumably partly as a cofactor for intrinsic membrane enzymes and partly believed to stabilize the membrane integrity.

The aim of the present study was to examine the effect of low or high de novo milk fat synthesis combined with a high or moderate level of dietary $\mathrm{Zn}$ on MFG size and stability. Furthermore, we intended to elucidate the effect of dietary $\mathrm{Zn}$ on membrane integrity; in this instance, the mammary gland's resistance toward mastitis pathogens and inflammation of the mammary tissue. The study was performed as a $4 \times 4$ Latin square design with 16 Holstein cows, 2 feeding rations expected to induce low or high de novo milk fat synthesis, and a high or moderate level of dietary Zn.

\section{MATERIALS AND METHODS}

\section{Cows, Design, Treatments, Collection of Samples, and Data}

The experiment was performed in the barns at Research Centre Foulum (Tjele, Denmark); cows were tied up in a barn with free access to drinking water. Sixteen Danish Holstein cows ( $89 \pm 17 \mathrm{~d}$ in lactation, $31.1 \pm 5.5$ $\mathrm{kg}$ of milk/d) were used in a $4 \times 4$ Latin square design with 4 groups of 4 cows, 4 dietary treatments, and 4 periods of $12 \mathrm{~d}$ each. The composition of the 4 feed treatments with 2 levels of saturated lipids and easily fermentable carbohydrates and 2 levels of dietary $\mathrm{Zn}$ are described in Table 1. All rations were based on corn silage, grass-clover silage and sugar beet pulp, and were optimized to be close to the same energy and protein values. Feeds were allocated ad libitum at 2 daily feedings (0630 and $1830 \mathrm{~h}$ ) as TMR. Individual feed DM content was determined weekly, and feed samples were collected weekly and frozen for further analysis. Feed intake was recorded daily. Milk yield was recorded at the evening milking on $\mathrm{d} 11$ and at the morning milking on d 12 in each period, and aliquots were sampled for analysis of fat, protein, and lactose (MilkoScan 4000, Foss Electric A/S, Hillerød, Denmark). Milk samples for analysis of MFG size were sampled at the morning milking on 11 and 12 , whereas milk samples for analysis of FFA, FA composition, and Zn content were sampled at the morning milking on d 12 only. Milk samples for analysis of FA composition and Zn content were frozen for later analysis.

Blood samples were taken from the jugular vein into Na-heparinized Vacutainers (Becton, Dickinson and Co., Plymouth, UK) at $0930 \mathrm{~h}$ on $\mathrm{d} 11$ and 12 in each period. Vacutainers were kept on ice until harvest of plasma by centrifugation at $2,000 \times g$ and $4^{\circ} \mathrm{C}$ for 20 min. Plasma samples were kept at $-20^{\circ} \mathrm{C}$ until analysis.

\section{Determination of the Particle Size Distribution of MFG}

Particle size distribution of MFG was determined by laser light scattering as described previously by Wiking et al. (2003). The volume-weighted diameter, $\mathrm{d}_{(4,3)}(\mu \mathrm{m})$, was calculated by the integrated software. This diameter was chosen instead of the surface-weighted diameter, $\mathrm{d}_{(3,2)}$, because volume-weighted diameter gives the best correlation to the fat content of milk (Wiking et al., 2004; Michalski et al., 2005).

\section{Analysis of FFA in Milk}

The concentration of FFA was analyzed immediately after milking $(0 \mathrm{~h})$ and another sample was incubated at $4^{\circ} \mathrm{C}$ for $28 \mathrm{~h}$ after milking. Free fatty acids concentration was analyzed by the Auto Analyzer II method (Lindqvist et al., 1975). The method is based on an extraction of the milk sample with an extraction and lipolytic inhibiting solution containing 2-propanol, heptane, and $1 \mathrm{~N} \mathrm{H}_{2} \mathrm{SO}_{4}$. In this method, the lipoprotein lipase (present in the aqueous phase) and the lipid are separated. In the auto-analyzer, the solution is mixed with the indicator reagent (phenol red, sodium barbital, and ethanol) and finally the absorbance is recorded at $560 \mathrm{~nm}$ in a colorimeter. The results are expressed in milliequivalents per one hundred grams of fat.

\section{Zinc in Feeds, Milk, and Blood}

Milk and feed samples were incinerated at $450^{\circ} \mathrm{C}$ and the ash solubilized in dilute nitric acid before analysis, whereas plasma samples were decomposed in a mixture of concentrated nitric acid and perchloric acid at $200^{\circ} \mathrm{C}$. The content of $\mathrm{Zn}$ was determined by atomic absorption spectrophotometry (Phillips SP9, Eindhoven, the Netherlands).

\section{Analytical Procedures for Lipid Metabolic Activity in Milk}

Milk samples were pipetted, diluted, and distributed to different analyses using a Biomek 2000 Laboratory Automation Workstation (Beckman Coulter, Fullerton, 
Table 1. Ingredient composition (\% of DM) and chemical composition of the 4 feed treatments and analyzed content of zinc $(\mathrm{Zn})$

\begin{tabular}{|c|c|c|c|c|}
\hline \multirow[b]{2}{*}{ Diet } & \multicolumn{2}{|c|}{ High de novo } & \multicolumn{2}{|c|}{ Low de novo } \\
\hline & $-\mathrm{ZnO}$ & $+\mathrm{ZnO}$ & $-\mathrm{ZnO}$ & $+\mathrm{ZnO}$ \\
\hline Corn silage & 30.8 & 30.8 & 33.3 & 33.3 \\
\hline Grass clover silage & 23.4 & 23.4 & 25.2 & 25.2 \\
\hline Sugar beet pulp & 14.2 & 14.2 & 15.3 & 15.3 \\
\hline Sugar beet molasses & 14.2 & 14.2 & & \\
\hline Rapeseed meal & 17.2 & 14.9 & & \\
\hline Rapeseed meal with $\mathrm{ZnO}^{1}$ & & 2.3 & & \\
\hline Rapeseed cake & & & 16.0 & 13.5 \\
\hline Rapeseed cake with $\mathrm{ZnO}^{1}$ & & & & 2.5 \\
\hline Corn & & & 8.2 & 8.2 \\
\hline Saturated lipid supplement ${ }^{2}$ & & & 1.8 & 1.8 \\
\hline Vitamin supplement & 0.2 & 0.2 & 0.2 & 0.2 \\
\hline $\mathrm{Zn}$ content $^{3}(\mathrm{mg} / \mathrm{kg}$ of $\mathrm{DM})$ & 39 & 83 & 34 & 80 \\
\hline \multicolumn{5}{|l|}{ Calculated composition ${ }^{4}$} \\
\hline $\mathrm{OM}(\mathrm{g} / \mathrm{kg}$ of DM) & \multicolumn{2}{|c|}{920} & \multicolumn{2}{|c|}{936} \\
\hline $\mathrm{CP}(\mathrm{g} / \mathrm{kg}$ of $\mathrm{DM})$ & \multicolumn{2}{|c|}{173} & \multicolumn{2}{|c|}{156} \\
\hline Crude fat ( $\mathrm{g} / \mathrm{kg}$ of $\mathrm{DM})$ & \multicolumn{2}{|c|}{26} & \multicolumn{2}{|c|}{66} \\
\hline Fatty acids ( $\mathrm{g} / \mathrm{kg}$ of $\mathrm{DM})$ & \multirow{2}{*}{\multicolumn{2}{|c|}{$\begin{array}{r}15 \\
104\end{array}$}} & \multirow{2}{*}{\multicolumn{2}{|c|}{$\begin{array}{r}48 \\
162\end{array}$}} \\
\hline Starch $(\mathrm{g} / \mathrm{kg}$ of $\mathrm{DM})$ & & & & \\
\hline Reducing sugars (g/kg of DM) & \multicolumn{2}{|c|}{129} & \multicolumn{2}{|c|}{47} \\
\hline $\mathrm{NDF}(\mathrm{g} / \mathrm{kg}$ of $\mathrm{DM})$ & \multicolumn{2}{|c|}{335} & \multicolumn{2}{|c|}{355} \\
\hline Digestibility of OM (\%) & \multirow{2}{*}{\multicolumn{2}{|c|}{$\begin{array}{l}80 \\
12\end{array}$}} & \multicolumn{2}{|c|}{80} \\
\hline $\mathrm{ME}(\mathrm{MJ} / \mathrm{kg}$ of $\mathrm{DM})$ & & & \multicolumn{2}{|c|}{12.9} \\
\hline
\end{tabular}

${ }^{1}$ Premixes with $\mathrm{ZnO}$ were used to obtain a uniform distribution of $\mathrm{ZnO}$ in the TMR.

${ }^{2}$ Containing $54 \%$ palmitic and $45 \%$ stearic acid as triglycerides (analysis by GC in our laboratory).

${ }^{3}$ Analyzed by atomic absorption spectrophotometry method.

${ }^{4}$ Calculated from standard values (NRC, 2001).

CA). Reagents for N-acetyl- $\beta$-D-glucosaminidase (NAGase), lactate dehydrogenase (LDH), alkaline phosphatase (AP), and BHBA assays were added in the robotic system as well as in the spectrophotometer/fluorometer Fluostar (BMG Labtechnologies, Offenburg, Germany). Analyses were performed in 96-well plates.

NAGase Activity. N-Acetyl- $\beta$-D-glucosaminidase (EC 3.2.1.30) was determined by a kinetic fluorometric assay, according to Kitchen et al. (1978) and Schüttel (1999); however, the composition of reagents and incubation times were slightly altered. Samples were incubated for $18 \mathrm{~min}$ in $37^{\circ} \mathrm{C}$ with citrate buffer, $\mathrm{pH} 4.6$, and substrate 4-methylumbelliferyl-N-acetyl- $\beta$-D-glucosaminide (Sigma, St Louis, MO). The hydrolysis was stopped by a Tritiplex glycine buffer (Merck, Darmstadt, Germany), $\mathrm{pH}$ 10.8; emission of $460 \mathrm{~nm}$ monochromatic light was measured after excitation with $355 \mathrm{~nm}$ light. Standards and controls were placed on every plate in duplicate. The accuracy (relative bias) was $3.9 \%$ (low) and $1.8 \%$ (high). Intraassay precision was 2.6 and 2.4 (coefficient of variation, CV\%), respectively, and interassay precision was 11.2 and 4.6 (CV\%), respectively, for low and high controls.

LDH Activity. Lactate dehydrogenase (EC 1.1.1.27) was analyzed according to Larsen (2005). Standards and controls were placed on every plate in duplicate.
The accuracy (relative bias) obtained in the present material was $2.7 \%$ (low) and $4.9 \%$ (high). Intraassay precision was 8.6 and 3.7 (CV\%), respectively, and interassay precision was 15.8 and 10.4 (CV\%), respectively, for low and high controls.

AP Activity. Alkaline phosphatase (EC 3.1.3.1) was determined using fluorometry. The substrate, 4methylumbelliferone phosphate, was incubated with the sample for $6 \mathrm{~min}$ in a diethanolamine buffer, $\mathrm{pH}$ 10.0. The reaction was stopped using a Tritiplex III glycine buffer, $\mathrm{pH} 10.8$, and the resulting fluorescence (emission wavelength $460 \mathrm{~nm}$ ) was measured after excitation with $355 \mathrm{~nm}$ monochromatic light. Standard curves were prepared on 4-methylumbelliferone in milk subjected to the same conditions. Standards and controls were placed on every plate in duplicate. The accuracy (relative bias) was $1.3 \%$ (low) and $4.4 \%$ (high). Intraassay precision was 4.8 and 2.7 (CV\%), respectively, and interassay precision was 17.2 and 4.7 (CV\%), respectively, for low and high controls.

$\boldsymbol{B H B A}$. $\beta$-Hydroxybutyrate was analyzed using the enzymatic oxidation of the metabolite. A coupled reaction was determination by fluorometry. The method is described by Larsen and Nielsen (2005). Within-plate precision was 3.0 and $5.6 \%$ (CV) and between-plate pre- 
Table 2. Average DMI, yield, ECM, fat and protein output, $\mathrm{Zn}$ in milk, and concentration of FFA in milk immediately after milking $(0 \mathrm{~h})$ and after $28 \mathrm{~h}$ at $4^{\circ} \mathrm{C}$

\begin{tabular}{|c|c|c|c|c|c|c|c|c|}
\hline \multirow[b]{2}{*}{ Diet } & \multicolumn{2}{|c|}{ High de novo } & \multicolumn{2}{|c|}{ Low de novo } & \multirow[b]{2}{*}{$\mathrm{SE}$} & \multicolumn{3}{|c|}{ Effect } \\
\hline & $-\mathrm{ZnO}$ & $+\mathrm{ZnO}$ & $-\mathrm{ZnO}$ & $+\mathrm{ZnO}$ & & Novo & $\mathrm{ZnO}$ & Novo $\times \mathrm{ZnO}$ \\
\hline DMI $(\mathrm{kg} /$ cow per $\mathrm{d})$ & 22.92 & 23.73 & 22.41 & 23.13 & 0.56 & NS & NS & NS \\
\hline Yield (kg) & 30.2 & 30.7 & 32.2 & 33.3 & 1.1 & $\dagger$ & $\mathrm{NS}$ & NS \\
\hline ECM $(\mathrm{kg})$ & 30.6 & 30.9 & 30.8 & 31.7 & 1.2 & NS & NS & NS \\
\hline Fat $(\%)$ & 3.98 & 4.07 & 3.82 & 3.75 & 0.1 & * & $\mathrm{NS}$ & NS \\
\hline Fat $(\mathrm{kg})$ & 1.23 & 1.25 & 1.23 & 1.26 & 0.06 & NS & NS & NS \\
\hline Protein $(\%)$ & 3.33 & 3.25 & 3.19 & 3.10 & 0.05 & $*$ & NS & NS \\
\hline Protein $(\mathrm{kg})$ & 1.01 & 1.02 & 1.03 & 1.04 & 0.04 & NS & NS & NS \\
\hline FFA at $0 \mathrm{~h}(\mathrm{mEq} / 100 \mathrm{~g}$ of fat $)$ & 0.60 & 0.58 & 0.59 & 0.59 & 0.02 & NS & NS & NS \\
\hline FFA at $28 \mathrm{~h}(\mathrm{mEq} / 100 \mathrm{~g}$ of fat $)$ & 0.92 & 1.04 & 1.18 & 1.00 & 0.1 & NS & NS & NS \\
\hline Zn (ppm) & 3.00 & 2.85 & 3.32 & 3.49 & 0.12 & $* * *$ & NS & NS \\
\hline
\end{tabular}

$\dagger P=0.11 ; * P<0.05 ; * * * P<0.001$

cision was 8.4 and $6.7 \%$, respectively, for low and high control samples.

\section{Analytical Procedures of Lipid Metabolic Activity in Blood}

Blood plasma NEFA were determined using the NEFA C acyl-CoA synthetase-acyl-CoA oxidase assay method (Wako Chemicals GmbH, Neuss, Germany). This NEFA analysis was able to detect plasma FFA larger than C5 (Johnson and Peters, 1993).

$\beta$-Hydroxybutyrate was determined spectrophotometrically as an increase in absorbance at $340 \mathrm{~nm}$ due to the production of $\mathrm{NADH}$, at slightly alkaline $\mathrm{pH}$ in the presence of $\beta-\mathrm{OH}$-butyrate dehydrogenase. Sample blank was included. The method involved oxamic acid in the media to inhibit lactate dehydrogenase as proposed by Harano et al. (1985).

Alkaline phosphatase activity was determined according to standard methods (Bayer Healthcare, Tarrytown, NY).

Isocitrate dehydrogenase $\left[\mathbf{I C D H}, \mathrm{NADP}^{+}\right.$oxidoreductase (decarboxylating); EC 1.1.1.42] activity was determined as an increase in absorbance due to oxidation of isocitrate to 2-oxoglutamate.

Malate dehydrogenase (MDH, $\mathrm{NAD}^{+}$oxidoreductase; EC 1.1.1.37) activity was determined as an increase in absorbance due to oxidation of malate to oxaloacetate and $\mathrm{NADH}+\mathrm{H}^{+}$.

All blood analyses were performed using an ADVIA 1650 Chemistry System autoanalyzer (Bayer Corporation, Tarrytown, NY). Intraassay variation (CV\%), interassay variation $(\mathrm{CV} \%)$, and relative bias (\% deviation from ideal value) was, in all instances, below the following values: NEFA: $0.9,5.0$, and 2.2 BHBA: 0.7, 2.6, and -0.9 ; AP: $2.6,2.7$, and -3.6 ; ICDH: 0.9 and 2.1 (no value for bias); and MDH: 0.7 and 2.0 (no value for bias).
Fatty acid composition of the milk fat was determined by GC separation and quantification as described by Wiking et al. (2003).

\section{Statistical Analyses}

The effect of $\mathrm{Zn}$ and fat supplement was analyzed using the PROC GLM procedure (SAS Institute, Cary, NC):

$$
\mathrm{Y}_{i j k l}=\mu+\mathrm{F}_{i}+\mathrm{Zn}_{j}+\mathrm{F} \times \mathrm{Zn}_{i j}+\varepsilon_{i j k l}
$$

where $\mathrm{Y}_{i j k l}=$ dependent variable; $\mu$ = overall mean; $\mathrm{F}_{i}=$ effect of feed ration ( $i=$ high de novo, low de novo); $\mathrm{Zn}_{j}=$ the effect of $\mathrm{Zn}$ supplements $(j=+,-) ; \mathrm{F} \times \mathbf{Z n}_{i j}=$ interactions between the 2 variables; and $\varepsilon_{i j k l}=$ residual error. $P<0.05$ was used as the significant threshold.

\section{RESULTS}

The dietary treatments did not affect DMI, milk yield, or ECM yield (Table 2). However, the high de novo diet resulted in greater $(P<0.05)$ fat and protein content compared with the low de novo diet (Table 2) but fat and protein yield were not significantly different between the diets. Table 2 shows that the dietary treatments had no effect on the concentration of FFA in milk immediately after milking or after $28 \mathrm{~h}$ at $4^{\circ} \mathrm{C}$. The concentration of FFA significantly increased during 28 $\mathrm{h}$ of storage at $4^{\circ} \mathrm{C}$. The average diameter of MFG in milk produced by cows offered the low de novo feed was greater $(P<0.05)$ compared with MFG from cows fed high de novo feed (Figure 1).

The atomic absorption analysis of the feed demonstrated that the level of $\mathrm{Zn}$ in the feed treatments varied from 34 to $83 \mathrm{mg} / \mathrm{kg}$ of DM, which was about twice the level of dietary $\mathrm{Zn}$ that we had planned. However, the concentration of $\mathrm{Zn}$ in milk was not significantly af- 


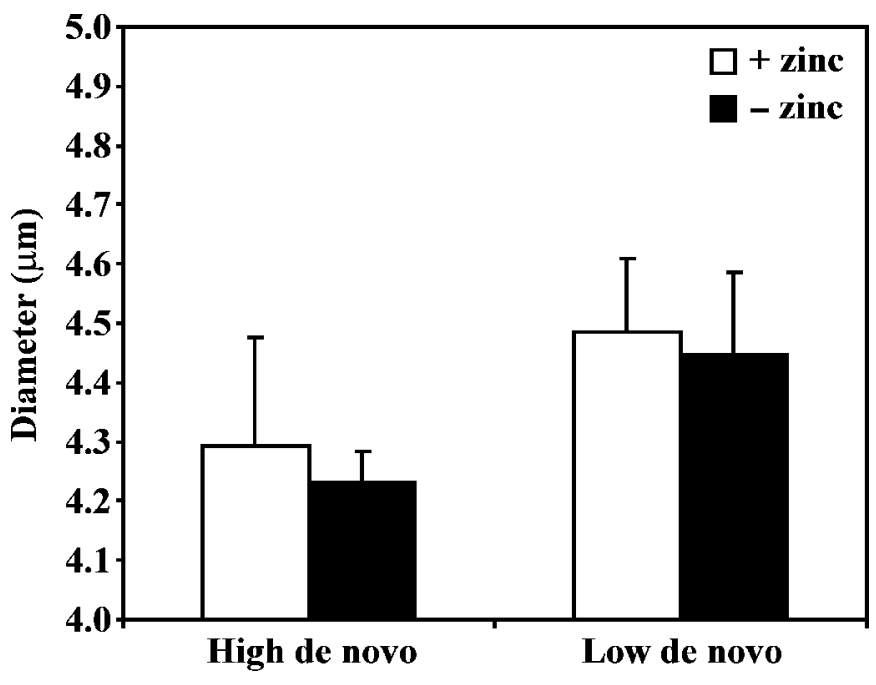

Figure 1. The volume-weighted diameter of fat globules from the raw milk of the different feedings: high or low level of milk fat and with or without supplemental zinc.

fected by dietary Zn supplement level; instead, the low de novo diet increased $(P<0.001)$ the concentration of $\mathrm{Zn}$ in milk compared with the high de novo diet (Table 2 ). The same pattern was observed in blood plasma.

Table 3 shows that the FA composition in milk was affected $(P<0.001)$ by the diet. The low de novo diet resulted in milk with relatively greater proportions of C18 and C18:1 and lower proportions of C6 to 14 and C16. The level of dietary Zn did not affect FA composition.

The activity of AP was increased $(P<0.01)$ in milk from cows fed the high de novo diet compared with animals fed the low de novo diet (Table 4). The BHBA concentration in milk was at the expected level (Larsen and Nielsen, 2005) and tended $(P=0.055)$ to be greater in milk from cows offered the high de novo diet. Activities of LDH and NAGase in milk were moderate and no significant difference between treatments was observed (Table 4). Dietary Zn level did not affect the enzyme activities or the BHBA level in milk.

The low de novo diet increased $(P<0.01)$ the concentration of NEFA in the blood of the cows (Table 5). Furthermore, an interaction $(P<0.01)$ between $\mathrm{Zn}$ and the de novo feeding was observed. The concentration of BHBA in blood plasma was greatest $(P<0.001)$ in the cows receiving the high de novo diet (Table 5). An interaction $(P<0.05)$ between $\mathrm{Zn}$ and the de novo feeding apparently also affected the concentration of BHBA in plasma. The activity of the enzymes ICDH and MDH was not affected by the different feeding regimens (Table 5).

\section{DISCUSSION}

The used level of saturated fat supplements and total dietary fat content was within the range recommended for dairy herds (NRC, 2001). Several studies have shown that increasing amounts of saturated fat supplement result in greater fat yield and ECM (Hermansen, 1989; Chilliard 1993). In contrast, Beaulieu and Palmquist (1995) observed no effect on milk fat yield or fat percentage by increasing the dietary intake of salts of palm FA. In the present study we intended to obtain similar milk fat yields on the high and low de novo diets, and, in fact, the measured milk fat yields did not differ, whereas the low de novo diet resulted in a lesser milk fat percentage than did the high de novo diet. The probable mechanism of obtaining the same level of milk fat yield on the 2 diets is that the change in dietary fat level was counteracted by changes in dietary molasses (sugars) and dietary corn (starch) levels, leading to a

Table 3. Fatty acid composition (g of fatty acid/100 g of milk) of milk fats produced by the various diets

\begin{tabular}{|c|c|c|c|c|c|c|}
\hline \multirow[b]{2}{*}{ Fatty acid } & \multicolumn{2}{|c|}{ High de novo } & \multicolumn{2}{|c|}{ Low de novo } & \multirow[b]{2}{*}{$\mathrm{SE}$} & \multirow{2}{*}{$\frac{\text { Effect }}{\text { Novo }}$} \\
\hline & $-\mathrm{ZnO}$ & $+\mathrm{ZnO}$ & $-\mathrm{ZnO}$ & $+\mathrm{ZnO}$ & & \\
\hline $\mathrm{C} 4$ & 0.172 & 0.177 & 0.169 & 0.161 & 0.006 & NS \\
\hline C6 & 0.117 & 0.111 & 0.096 & 0.095 & 0.003 & $* * *$ \\
\hline C8 & 0.068 & 0.072 & 0.056 & 0.055 & 0.002 & $* * *$ \\
\hline C10 & 0.160 & 0.171 & 0.119 & 0.117 & 0.005 & $* * *$ \\
\hline C12 & 0.163 & 0.174 & 0.113 & 0.111 & 0.005 & $* * *$ \\
\hline C14 & 0.511 & 0.532 & 0.419 & 0.419 & 0.012 & $* * *$ \\
\hline C14:1 & 0.046 & 0.047 & 0.035 & 0.036 & 0.002 & $* * *$ \\
\hline C16 & 1.550 & 1.590 & 1.140 & 1.130 & 0.050 & $* * *$ \\
\hline C16:1 & 0.088 & 0.087 & 0.059 & 0.059 & 0.005 & $* * *$ \\
\hline C18 & 0.340 & 0.328 & 0.561 & 0.549 & 0.022 & $* * *$ \\
\hline C18:1 & 0.678 & 0.649 & 0.940 & 0.890 & 0.035 & $* * *$ \\
\hline C18:2 & 0.088 & 0.089 & 0.093 & 0.093 & 0.004 & NS \\
\hline C18:3 & 0.030 & 0.032 & 0.029 & 0.029 & 0.002 & NS \\
\hline C20:4 & 0.004 & 0.004 & 0.005 & 0.003 & 0.001 & NS \\
\hline
\end{tabular}


Table 4. Activity of alkaline phosphatase (AP), BHBA, lactate dehydrogenase (LDH), and N-acetyl- $\beta$-Dglucosaminidase (NAGase) in milk produced by the various diets

\begin{tabular}{|c|c|c|c|c|c|c|c|c|}
\hline \multirow[b]{2}{*}{ Enzyme } & \multicolumn{2}{|c|}{ High de novo } & \multicolumn{2}{|c|}{ Low de novo } & \multirow[b]{2}{*}{$\mathrm{SE}$} & \multicolumn{3}{|c|}{ Effect } \\
\hline & $-\mathrm{ZnO}$ & $+\mathrm{ZnO}$ & $-\mathrm{ZnO}$ & $+\mathrm{ZnO}$ & & Novo & $\mathrm{ZnO}$ & Novo $\times \mathrm{Zn}$ \\
\hline $\mathrm{AP}(\mathrm{U} / \mathrm{L})$ & 305 & 302 & 265 & 250 & 23 & * & NS & NS \\
\hline BHBA $(\mu M)$ & 59 & 62 & 58 & 55 & 2 & $\dagger$ & NS & NS \\
\hline $\mathrm{LDH}(\mathrm{U} / \mathrm{L})$ & 2.67 & 2.81 & 2.98 & 2.64 & 0.16 & NS & NS & NS \\
\hline NAGase (U/L) & 1.89 & 1.94 & 1.82 & 1.91 & 0.12 & NS & NS & NS \\
\hline
\end{tabular}

$\dagger P=0.055 ; * P<0.05$.

changed ruminal formation of precursors (acetate and BHBA) for mammary de novo FA synthesis. The supposed change toward ruminal formation of glucogenic propionate from the starch-rich low de novo diet is underlined by the tendency of a greater and more dilute milk yield on this diet.

The ration fed and the use of saturated lipid supplement was not expected to induce milk fat depression, and the milk fat concentration obtained in the present study confirmed that there was no milk fat depression as defined by Bauman and Griinari (2001). Although de novo milk fat synthesis might be reduced by high levels of long-chain FA deriving from feed on the low de novo diet, it is noteworthy that an equally high milk fat yield could be obtained on the high de novo diet with a relatively low dietary FA content.

The present decrease in milk protein percentage when feeding saturated lipid supplements is comparable to results of other studies (Hermansen, 1989; Chilliard, 1993). The decrease is often explained as a dilution of a constant protein production, resulting in increased milk production, and this also seems to be the case in the present study, because the protein yields did not differ between treatments.

Activities of NAGase and LDH in milk are well-documented indicators of bovine mastitis (e.g., Chagunda et al., 2006). The levels of enzyme activity in the present material do not support any speculation of infected or inflamed udders that in any way could affect the present composition or quantity of milk. On the contrary, the range of the enzyme activities measured in the milk throughout the experiment clearly signals healthy glands and animals. The present study furthermore tends to reject the idea that additional dietary $\mathrm{Zn}$ would improve the stability of the gland tissue membranes. However, the inherent health level of the cows participating in the present study was high.

Both $\mathrm{MDH}$ and ICDH enzymes are involved in producing the reducing equivalents $\mathrm{NADH}$ and NADPH, respectively. Both enzymes appear in all tissues in the cytoplasmic phase as well as inside the mitochondria. In particular, ICDH might be of specific importance in cows producing milk because ICDH activity is especially abundant in mammary glands of cows, and this enzyme is believed to deliver a considerable amount of the energy used in elongation of milk FA during de novo synthesis (Bauman et al., 1970). Generally, the ICDH activity in the gland is found to be positively correlated with milk production (Waldschmidt and Rilling, 1973), which is in accordance with the present circumstances. However, in the present study, no difference in ICDH activity was observed in blood plasma between cows because of feeding strategies, indicating that blood ICDH activity is not reflecting mammary tissue activity in this instance.

The obtained difference between the FA composition of milk fat from cows fed the low or high de novo diets was as expected and similar to an earlier study in which fat supplements rich in $\mathrm{C} 16$ and $\mathrm{C} 18$ were used (Wiking et al., 2003). In that earlier study we observed a slight

Table 5. Activity of alkaline phosphatase (AP), malate dehydrogenase activity (MDH), isocitrate dehydrogenase activity (ICDH), and concentration of NEFA, BHBA, and Zn in blood plasma

\begin{tabular}{|c|c|c|c|c|c|c|c|c|}
\hline \multirow[b]{2}{*}{ Item } & \multicolumn{2}{|c|}{ High de novo } & \multicolumn{2}{|c|}{ Low de novo } & \multirow[b]{2}{*}{$\mathrm{SE}$} & \multicolumn{3}{|c|}{ Effect } \\
\hline & $-\mathrm{ZnO}$ & $+\mathrm{ZnO}$ & $-\mathrm{ZnO}$ & $+\mathrm{ZnO}$ & & Novo & $\mathrm{ZnO}$ & Novo $\times \mathrm{Zn}$ \\
\hline NEFA $(\mu \mathrm{Eq} / \mathrm{L})$ & 60 & 50 & 62 & 71 & 4 & $* *$ & NS & * \\
\hline $\mathrm{AP}(\mathrm{U} / \mathrm{L})$ & 27.0 & 26.5 & 27.6 & 28.5 & 1.3 & NS & NS & $\mathrm{NS}$ \\
\hline BHBA $(\mu M)$ & 0.91 & 1.01 & 0.76 & 0.85 & 0.04 & *** & NS & * \\
\hline ICDH (U/L) & 104 & 101 & 108 & 106 & 4 & NS & NS & NS \\
\hline MDH (U/L) & 96.9 & 95.1 & 99.1 & 95.6 & 1.10 & NS & NS & NS \\
\hline $\mathrm{Zn}(\mathrm{ppm})$ & 0.90 & 0.89 & 1.01 & 1.10 & 0.03 & **** & NS & NS \\
\hline
\end{tabular}

$* P<0.05 ; * * P<0.01 ; * * * P<0.001$. 
increase in the proportion of $\mathrm{C} 16$ when using saturated fat supplement in contrast to the significant decrease in concentration of $\mathrm{C} 16$ found in the present study. Because C16 in milk is synthesized both de novo and directly from the feed, the result can vary depending upon the dietary fat supplement.

The increased average diameter of MFG in milk from cows fed the low de novo diet is in agreement with results obtained by Wiking et al. (2003, 2005). However, in the present study the fat percentage was not greater in milk from cows offered the low de novo diet. It has formerly been shown that increasing fat yield results in increasing average diameter of MFG (Wiking et al., 2004). Furthermore, the concentration of $\mathrm{C} 16, \mathrm{C} 18$, and C18:1 correlates positively with average diameter of the MFG (Wiking et al., 2004), and the high proportion of these FA in milk from the low de novo diet observed in the present study could explain the significantly greater average diameter of MFG. Altogether, this confirms that MFG size increases as the proportion of de novo synthesized milk FA decreases. The explanation could be that saturated milk lipids (C16 and C18) crystallize and therefore have a greater volume than liquid fat.

The level of $\mathrm{Zn}$ in the feed varied markedly in the experimental diets. However, this did not affect the concentration of $\mathrm{Zn}$ in plasma and milk. On the contrary, the low de novo diet rendered significantly greater concentrations of $\mathrm{Zn}$ in plasma and milk than the high de novo diet. Sol Morales et al. (2000) observed that the concentration of $\mathrm{Zn}$ and copper in plasma was lower in cows fed soybeans compared with tallow. This indicates that the degree of saturation of the fat source affects the concentration of $\mathrm{Zn}$ in plasma and thus in milk. Hermansen et al. (1995) found that feeding a high concentration of $\mathrm{Zn}$ only tended to increase the concentration of $\mathrm{Zn}$ in whole milk but significantly increased the concentration in the cream fraction. The concentrations of $\mathrm{Zn}$ in milk and plasma found in our study are within the range of other studies (Anderson, 1992; Sol Morales et al., 2000; NRC, 2001). To our knowledge, the present study is the first to indicate that the plasma and milk $\mathrm{Zn}$ levels are increased by saturated lipid in the diet, and thereby that dietary fat might facilitate the transfer of dietary $\mathrm{Zn}$ into plasma and milk.

It was expected that dietary Zn would decrease the accumulation of FFA in milk, as indicated in an earlier study (Hermansen et al., 1995). However, the present study did not confirm that dietary Zn affects lipolysis in milk. Furthermore, the current study indicates that the use of fat supplement has no effect on spontaneous lipolysis under the present circumstances. Formerly it was demonstrated that high levels of saturated fat supplements increase lipolysis in the produced milk during pumping (Wiking et al., 2003, 2005). In the earlier cited studies, the levels of saturated fat supplements were greater and the fat was given as FFA, in contrast to the present study, in which the fat was given as triglycerides, because this should affect the rumen bacteria to a lesser degree. Furthermore, in the present we only focus on spontaneous liposysis. The earlier studies have examined induced lipolysis (i.e., pumping), in which the size of the MFG had a greater impact because of the increased coalescence energy between globules and lower surface tension (Wiking et al., 2003, 2005)

Alkaline phosphatase is a well-recognized enzyme in cow's milk. Its activity and distribution have been the object of several investigations (e.g., Kitchen et al., 1970; Kitchen, 1974). The activity is known to be present in the skim milk fraction as well as in the cream fraction, often connected to membrane material (Kitchen, 1974; Fransson and Lönnerdal, 1984). Furthermore, AP is a well known metalloprotein, dependent upon $\mathrm{Zn}$ for its catalytic function, requiring several $\mathrm{Zn}$ ions per functional unit of enzyme. The present study, however, revealed an inverse relationship between $\mathrm{Zn}$ content and AP activity in milk, indicating that the $\mathrm{Zn}$ content is not limiting for the AP activity in milk under the present circumstances. However, AP activity in milk seems to be positively correlated to milk fat membrane material, because the high de novo diet both show greater AP activity and smaller volumeweighted diameter of fat globules; that is, more membrane material per volume of fat.

\section{CONCLUSIONS}

A high de novo diet based on low dietary fat and starch levels and high dietary sugar (molasses) can result in milk with a greater fat percentage and equal fat yield compared with a diet in which the dietary molasses were substituted by starch and saturated fat supplements. Furthermore, the study implies that the transfer of fat from diet to milk might facilitate transfer of $\mathrm{Zn}$ from diet to milk. Our study could not support the hypothesis that dietary Zn limited the formation of FFA in milk through stabilization of the MFGM. Likewise, the activity of mastitis indicators was not affected by dietary $\mathrm{Zn}$.

\section{ACKNOWLEDGMENTS}

We thank Rita Albrechtsen, Jens Clausen, and Carsten Berthelsen for skilled technical assistance. This work was financially supported by the Danish Dairy Research Foundation. 


\section{REFERENCES}

Anderson, R. R. 1992. Comparison of trace elements in milk of four species. J. Dairy Sci. 75:3050-3055.

Astrup, H. N., L. Vik-Mo, O. Skrøvseth, and A. Ekern. 1980. Milk lipolysis when feeding saturated fatty acids to the cow. Milchwissenschaft 35:1-4.

Bauman, D. E., R. E. Brown, and C. L. Davis. 1970. Pathways of fatty acid synthesis and reducing equivalent generation in mammary gland of rat, sow, and cow. Arch. Biochem. Biophys. 140:237-244.

Bauman, D. E., and J. M. Griinari. 2001. Regulation and nutritional manipulation of milk fat: Low-fat milk syndrome. Livest. Prod. Sci. 70:15-29.

Beaulieu, A. D., and D. L. Palmquist. 1995. Differential effects of high fat diets on fatty acid composition in milk of Jersey and Holstein cows. J. Dairy Sci. 78:1336-1344.

Chagunda, M. G. G., T. Larsen, M. Bjerring, and K. L. Ingvartsen. 2006 . L-lactate dehydrogenase and N-acetyl- $\beta$-D-glucosaminidase activities in bovine milk as indicators of non-specific mastitis. J. Dairy Res. 73:431-440.

Chilliard, Y. 1993. Dietary fat and adipose tissue metabolism in ruminants, pigs, and rodents: A review. J. Dairy Sci. 76:3897-3931.

Chvapil, M. 1976. Effect of zinc on cells and biomembranes. Med. Clin. North Am. 60:799-812.

Fransson, G. B., and B. Lönnerdal. 1984. Iron, copper, zinc, calcium, and magnesium in human milk fat. Am. J. Clin. Nutr. 39:185-189.

Harano, Y., M. Ohtsuki, M. Ida, H. Kojima, M. Harada, T. Okanishi, A. Kashiwagi, Y. Ochi, S. Uno, and Y. Shigeta. 1985. Direct automated assay method for serum or urine levels of ketone bodies. Clin. Chim. Acta 151:177-183.

Hermansen, J. E. 1989. Feed intake and milk yield at increasing supplement of a palmitic and stearic-rich type of fat in comparison with animal fat. Anim. Feed Sci. Technol. 22:179-191.

Hermansen, J. E., T. Larsen, and J. O. Andersen. 1995. Does zinc play a role in the resistance of milk to spontaneous lipolysis? Int. Dairy J. 5:473-481.

Johnson, A. H. 1974. The composition of milk. Pages 1-57 in Fundamentals of Dairy Chemistry. B. H. Webb, A. H. Johnson and J. A. Alford, ed. Avi Publishing, Westport, CT.

Johnson, M. M., and J. P. Peters. 1993. An improved method to quantify nonesterified fatty acids in bovine plasma. J. Anim. Sci. 71:753-756.

Kitchen, B. J. 1974. A comparison of the proporties of membranes isolated from bovine skim milk and cream. Biochim. Biophys. Acta 356:257-269.
Kitchen, B. J., G. Middleton, and L. Salmon. 1978. Bovine milk Nacetyl- $\beta$-D-glucosaminidase and its significance in the detection of abnormal udder secretions. J. Dairy Sci. 45:15-20.

Kitchen, B. J., G. C. Taylor, and I. C. White. 1970. Milk enzymes Their distribution and activity. J. Dairy Res. 37:279-288.

Larsen, T. 2005. Determination of lactate dehydrogenase (LDH) activity in milk by a fluorometric assay. J. Dairy Res. 72:209-216.

Larsen, T., and N. I. Nielsen. 2005. Fluorometric determination of $\beta$-hydroxybutyrate in milk and blood plasma. J. Dairy Sci. 88:2004-2009

Lindén, M. V., S. K. Wiedmer, S. Hakala, and M.-L. Riekkola. 2004. Stabilization of phosphatidylcholine coatings in capillary electrophoresis by increase in membrane rigidity. J. Chromatogr. A. 1051:61-68.

Lindqvist, B., T. Roos, and H. Fujita. 1975. Auto-analyzer determination of free fatty acids in farm millk. Modification of present method to simplify transportation of the sample. Milchwissenschaft 30:12-17.

Michalski, M. C., V. Briard, F. Michel, F. Tasson, and P. Poulain. 2005. Size distribution of fat globules in human colostrum, breast milk, and infant formula. J. Dairy Sci. 88:1927-1940.

Mulder, H., and P. Walstra. 1974. The milk fat globule. Emulsions science as applied to milk products and comparable foods. Commonwealth Agricultural Bureaux Farnham Royal., Bucks, UK.

NRC. 2001. Nutrient Requirements of Dairy Cattle. 7th rev. ed. Natl. Res. Council, Natl. Acad. Press, Washington, DC.

Schüttel, M. 1999. Vergleich von N-acetyl- $\beta$-D-glycosaminidase-Aktivitäten (NAGase) in Milch, Blut und Harn beim laktierenden Rind. Diss. Tierärtslicher Hochschule, Hannover, Germany.

Sol Morales, M., D. L. Palmquist, and W. P. Weiss. 2000. Milk fat composition of Holstein and Jersey cows with control or depleted copper status and fed whole soybeans or tallow. J. Dairy Sci. 83:2112-2119.

Waldschmidt, M., and S. Rilling. 1973. Metabolite levels and enzyme activities in the bovine mammary gland in different stages of lactation. J. Dairy Res. 40:361-370.

Wiking, L., H. C. Bertram, L. Björck, and J. H. Nielsen. 2005. Evaluation of cooling strategies for pumping of milk - Impact of fatty acid composition on free fatty acid levels. J. Dairy Res. 72:476-481.

Wiking, L., L. Björck, and J. H. Nielsen. 2003. Influence of feed composition on stability of fat globules during pumping of raw milk. Int. Dairy J. 13:797-803.

Wiking, L., J. Stagsted, L. Björck, and J. H. Nielsen. 2004. Milk fat globule size is affected by fat production in dairy cows. Int. Dairy J. 14:909-913. 